\title{
Itaipu Reservoir limnology: eutrophication degree and the horizontal distribution of its limnological variables
}

\author{
Ribeiro Filho, RA. ${ }^{a *}$, Petrere Junior, M. ${ }^{b, c *}$, Benassi, SF. ${ }^{d}$ and Pereira, JMA. ${ }^{a}$ \\ ${ }^{\text {a } D e p a r t a m e n t o ~ d e ~ E n g e n h a r i a ~ d e ~ P e s c a ~ e ~ A q u i c u l t u r a, ~ U n i v e r s i d a d e ~ F e d e r a l ~ d e ~ R o n d o ̂ n i a ~-~ U N I R, ~}$ \\ Rua da Paz, 4376, CEP 76916-000, Presidente Médici, RO, Brazil \\ ${ }^{\text {b}}$ Departamento de Ecologia, Instituto de Biociências, Universidade Estadual Paulista - UNESP, \\ CP 199, CEP 13506-900, Rio Claro, SP, Brazil \\ 'Departamento de Direito Ambiental, Universidade do Estado do Amazonas - UEA, \\ Rua Leonardo Malcher, 1728, Praça XV, Ed. Professor Samuel Benchimol, $5^{\circ}$ andar, CEP 69020-170, Manaus, AM, Brazil \\ ${ }^{\mathrm{d} D i v i s a ̃ o ~ d e ~ R e s e r v a t o ́ r i o ~(M A R R . C D), ~ S u p e r i n t e n d e ̂ n c i a ~ d e ~ M e i o ~ A m b i e n t e, ~}$ \\ Itaipu Binacional, CEP 85866-900, Foz do Iguaçu, PR, Brazil \\ *e-mail: mpetrere@ rc.unesp.br; rarfilho@gmail.com
}

Received August 9, 2010 - Accepted January 10, 2011 - Distributed November 30, 2011

(With 8 figures)

\begin{abstract}
Reservoirs are manmade habitats, intermediate between rivers and lakes, presenting distinct hydrological and morphometric characteristics, with differential mean water residence time. They also present proper vertical and horizontal organisations, and their evolution depends on several variables acting on different special and temporal scales. The water quality evolution of the Itaipu Reservoir was evaluated through the analysis of the physical, chemical and biological variables, and by the application of Trophic State Indices. We concluded that the limnological variables present a horizontal pattern of variation highly dependent upon the hydrological regime. The turbidity and total suspended solids presented the same distribution pattern in the reservoir zones. The fluvial zone had the highest concentrations of nutrients, suspended solids and turbidity. The results of the Trophic State Indices indicate a mesotrophic level for the fluvial and transition zones, and an oligotrophic one for the lacustrine zone.
\end{abstract}

Keywords: limnology, Itaipu reservoir, water quality, eutrophication, Brazil.

\section{Limnologia no reservatório de Itaipu: grau de eutrofização e distribuição horizontal de suas variáveis limnológicas}

\section{Resumo}

Os reservatórios são ambientes artificiais e intermediários entre rios e lagos, apresentando características morfométricas e hidrológicas distintas, com alta taxa de renovação da água e organizações vertical e horizontal características. A evolução desses ecossistemas depende de variáveis que atuam em diferentes escalas espaciais e temporais. A evolução da qualidade da água do Reservatório de Itaipu foi avaliada por meio da análise das variáveis físicas, químicas e biológicas e da aplicação de índices de Estado Trófico. Observou-se que as variáveis limnológicas químicas e físicas apresentaram um padrão de variação espacial (horizontal) e temporal fortemente dependente do regime hidrológico. Os efeitos da turbidez e os sólidos suspensos totais apresentaram o mesmo padrão de distribuição por zona do reservatório. A zona fluvial foi a que apresentou as maiores concentrações de nutrientes, sólidos suspensos e turbidez. Os resultados dos Índices de Estado Trófico indicaram um estado de mesotrofia para as zonas fluvial e de transição e oligotrofia para a zona lacustre.

Palavras-chave: limnologia, reservatório de Itaipu, qualidade da água, eutrofização, Brasil. 


\section{Introduction}

Reservoirs are manmade ecosystems, intermediary between rivers and lakes, presenting distinct morphometric and hydrological characteristics, with differential vertical and horizontal organisations. Their evolution depends on countless variables distributed in spatial and temporal scales (Margalef, 1975).

Reservoirs are similar to lakes as for the basic ecological processes which involve the individual, community and ecosystem metabolisms, as well as their regulating factors (Wetzel, 1990). However, the need to regulate their flow according to the energy demand or due to other purposes, alters their water level, depth and mean water residence time (MWRT) and influences their chemical, physical and biological attributes.

According to Straškraba and Tundisi (2000), when one discusses aspects of reservoir water quality it is wise to consider the ecosystem divided in subsystems which interact amongst themselves such as: i) the hydrographic basin; ii) the flow; iii) the reservoir in itself; iv) the released flow and v) its administration and consequent socioeconomy. These authors point out that reservoirs are collectors and digesters of the inputs and of the existent effects in their basin. These effects include physical, chemical and biological internal processes.

It is well accepted that along rivers to dams, mainly in larger reservoirs, it is possible to discern three zones that differ in physical, chemical and biological properties: i) the fluvial, ii) the transition and iii) the lacustrine zones (Agostinho et al. 2005, 2007; Ribeiro Filho 2006, 2008). The dimensioning of these three zones is strongly related to the water influx and to its MWRT. In general, MWRT increases whereas the nutrient and seston concentrations decrease towards the dam. This affects the main functioning controlling phytoplankton productivity, which is the nutrient load and MWRT, affecting, as a consequence, the reservoirs' biological communities.

The aims of this paper are to evaluate the water quality variation of the Itaipu Reservoir in its central body and its left (Brazilian) margin arms and its longitudinal variation, through analysis of the physical, chemical and biological variables, considering its multiple uses.

\section{Methods and Materials}

\subsection{The Itaipu reservoir}

The Itaipu dam (Figure 1) was closed in October 1982. It is located in the Brazilian-Paraguayan border, between $24^{\circ} 05^{\prime} \mathrm{S}$ and $25^{\circ} 33^{\prime} \mathrm{S}$ and between $54^{\circ} 00^{\prime} \mathrm{W}$ and $54^{\circ} 37^{\prime} \mathrm{W}$. Its surface area varies from $1350 \mathrm{~km}^{2}$ (referent to a water column of $220 \mathrm{~m}$ ) to $1460 \mathrm{~km}^{2}(223 \mathrm{~m})$, from which $625 \mathrm{~km}^{2}$ belongs to Brazil and $835 \mathrm{~km}^{2}$, to Paraguay. Its main axis separates the cities of Guaira in Brazil and Salto de Guayrá in Paraguay and also Foz do Iguaçu (Brazil) and Ciudad de Leste (Paraguay) (Agostinho et al., 1999).

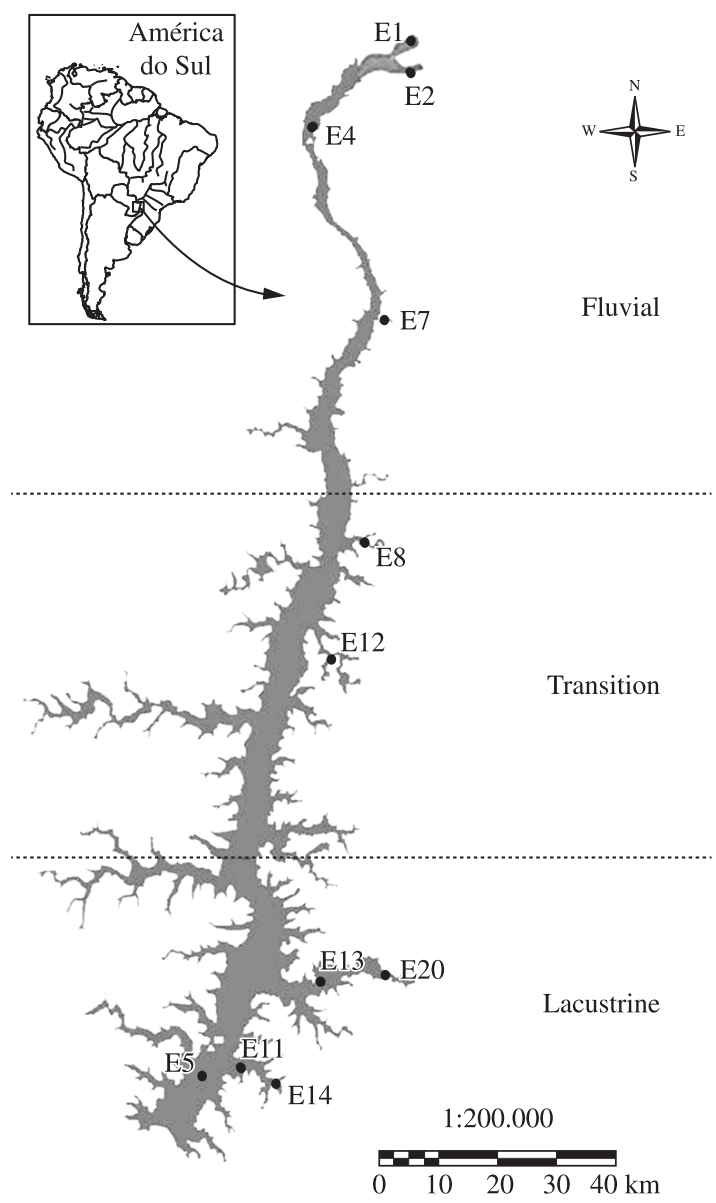

Figure 1. Paraná River basin depicting the main Itaipu reservoir zones and the sampling sites.

\subsection{Data}

The data were supplied by Itaipu Binacional. The physical, chemical and biological water variables were collected by the Instituto Ambiental do Paraná (IAP).

According to IAP (2003), the samples were collected from the water surface, and the physical, chemical and biological variables were quarterly monitored. The following variables were measured in the field: water transparency (Secchi Disk), turbidity and total suspended solids; in the laboratory, according to APHA (1985) were analyzed the variables: total nitrogen Kjeldahl (TKN), suspended solids, total phosphorous and chlorophyll- $a$. The samples were collected with a Van Dorn bottle (5.5 L).

The sampling points were divided into three zones according to the method proposed by Agostinho et al. $(2005,2007)$ and Ribeiro-Filho $(2006,2008)$. Although the sampling was carried out mostly in the arms, these are influenced by the Paraná River, and are thus believed to largely reflect the behaviour of these areas, originally attributed only to the main body of the reservoir. 


\subsection{Trophic state index (TSI)}

In order to evaluate the trophic state of the Itaipu Reservoir, the index originally proposed by Carlson modified by Toledo Junior et al. (1983) was used (Equations 1-3).

$\operatorname{TSI}($ Secchi $)=10\left[6-\left(\frac{0.64+\ln \text { Secchi }}{\ln 2}\right)\right]$

$\operatorname{TSI}\left(\mathrm{P}_{\text {total }}\right)=10\left[6-\left(\frac{\ln \left\{80.32 / \mathrm{P}_{\text {total }}\right\}}{\ln 2}\right)\right]$

$\operatorname{TSI}($ Chlorophyll $)=10\left[6-\left(\frac{2.04-0.695 * \ln \text { Chlorophyll }}{\ln 2}\right)\right](3)$

For determining the mean TSI, the calculation of this index was carried out using the weighed mean, attributing a lesser weight to the water transparency, as suggested by Toledo Junior et al. (1983). So the Equation 4 was used.

$\operatorname{TSI}($ mean $)=\frac{\operatorname{TSI}(\text { Secchi })+2[\operatorname{TSI}(\text { Ptotal })+\operatorname{TSI}(\text { Chlorophyll })]}{5}(4)$

\subsection{Statistical analyses}

Possible differences between the zones of the Reservoir were checked through ANOVAs $(\mathrm{p}<0.005)$ applied for each of the limnological variables and for the trophic state index. The normality was checked by Lilliefors Test.

\section{Results}

\subsection{Limnological variables}

Water transparency variation in the Itaipu Reservoir presented the same trend in distribution between all zones, regarding the temporal variation. The mean global transparency was $1.16 \mathrm{~m}(\mathrm{n}=930 ; \mathrm{SD}=0.65)$, the peaks were $5.76 \mathrm{~m}$ in the fluvial zone, $4.86 \mathrm{~m}$ in the transition zone and $2.83 \mathrm{~m}$ in the lacustrine zone (Figure 2). Although the peak was found in the river area, statistical analysis indicated the highest average of transparency in the lacustrine area $(\mathrm{p}<0.05)$ (Table 1a).

Figure 3 shows the distribution of the total suspended solids. The mean global value for the reservoir was $11.86 \mathrm{mg} / \mathrm{L}(\mathrm{n}=558 ; \mathrm{SD}=17.51)$; the maximum values were $108.00 \mathrm{~m} / \mathrm{L}$ in the fluvial zone, $36.00 \mathrm{mg} / \mathrm{L}$ in the transition zone and $49.00 \mathrm{mg} / \mathrm{L}$ in the lacustrine zone (Figure 4); the minimum concentration were under $1.00 \mathrm{mg} / \mathrm{L}$ in the three zones. There were differences $(\mathrm{p}<0.05)$ between fluvial and transition zones, and fluvial and lacustrine zones, but not between lacustrine and transition zones (Table 1b)

The turbidity values were homogeneous just in the lacustrine zone. The peaks of 187 NTU were registered in 2004 and 142 NTU in 1990 (in the transition and fluvial zones, respectively), and the smallest value was of 2 NTU in the lacustrine zone. Statistical analysis showed differences $(p<0.05)$ between the three zones and the fluvial zone had the greatest mean (Table 1c).
The peak of TKN concentration was observed in the lacustrine zone (1.200 mg/L) in September/1995 (Figure 5). The mean TKN concentration was of $0.363 \mathrm{mg} / \mathrm{L}(\mathrm{n}=369$; $\mathrm{SD}=0.184$ ) and the minimum value of $0.035 \mathrm{mg} / \mathrm{L}$, measured in the transition zone, in May/1999. There were statistical differences $(p<0.05)$ between the three reservoir zones (Table 1d).

The highest value for the total phosphorous concentration was found in November/1987 (0.324 mg/L), in the fluvial zone, and the mean global concentration was $0.031 \mathrm{mg} / \mathrm{L}$ $(\mathrm{n}=931 ; \mathrm{SD}=0.031)$ (Figura 6). There were statistical differences $(\mathrm{p}<0.05)$ between the three reservoir zones (Table 1e).

The fluvial and lacustrine zones presented the lowest mean chlorophyll- $a$ concentrations: $6.1 \mathrm{mg} / \mathrm{m}^{3}(\mathrm{n}=328$; $\mathrm{SD}=4.2)$ and $8.9 \mathrm{mg} / \mathrm{m}^{3}(\mathrm{n}=362 ; \mathrm{SD}=27.4)$, respectively (Figure 7). The mean chlorophyll- $a$ concentration in the reservoir was of $9.2 \mathrm{mg} / \mathrm{m}^{3}(\mathrm{n}=842 ; \mathrm{SD}=22.5)$. The fluvial and lacustrine zones did not present statistical difference, but the fluvial and transition zones, and lacustrine and transition zones had statistical differences $(\mathrm{p}<0.05)$ (Table 1f).

\subsection{Trophic state index}

Figure 8 displays the mean TSI values. The fluvial zone presented highest value in November/1987 (129.96). The transition zone presented the lowest value in May/1989 (14.28). The mean TSI for the whole reservoir is 45.99 ( $\mathrm{n}=829 ; \mathrm{SD}=7.28$ ) which classify it as mesotrophic. This value, however, was close to the lower limit value classified as oligotrophic $(<45)$. When one considers the three zones separately, the lacustrine zone may be considered oligotrophic as its mean value is $43.05(n=357$; $\mathrm{SD}=7.36)$. The fluvial and transition zones present values of $48.11(n=321 ; \mathrm{SD}=6.08)$ and $48.43(\mathrm{n}=151$; $\mathrm{SD}=7.02$ ), respectively, being classified as mesotrophic. Statistical analysis corroborates these values: the fluvial and transition zone did not differ, but lacustrine zone was different from the zones $(\mathrm{p}<0.05)$ (Table $1 \mathrm{~g})$.

\section{Discussion}

The three main zones of large reservoirs (Kimmel, 1990) have a horizontal spatial distribution, with their own dynamics, balancing the input/output. This author points out that there is a temporary compartmentalisation depending on the horizontal flow in the surface. It is subject to wind action and to the water masses distribution with different densities. According to Tundisi (1990), the horizontal distribution of the limnological variables in a reservoir is related to the following factors: i) advection currents generated by rivers entrance; ii) surface currents due to wind action and iii) currents due to the horizontal flow, consequence of water masses exit in several depths.

According to Thornton (1990) the relationships among the three reservoir zones suggest that the seasonal variability is explained by the hydrodynamical process, the reservoir presents different variations in its zones and so the particles 

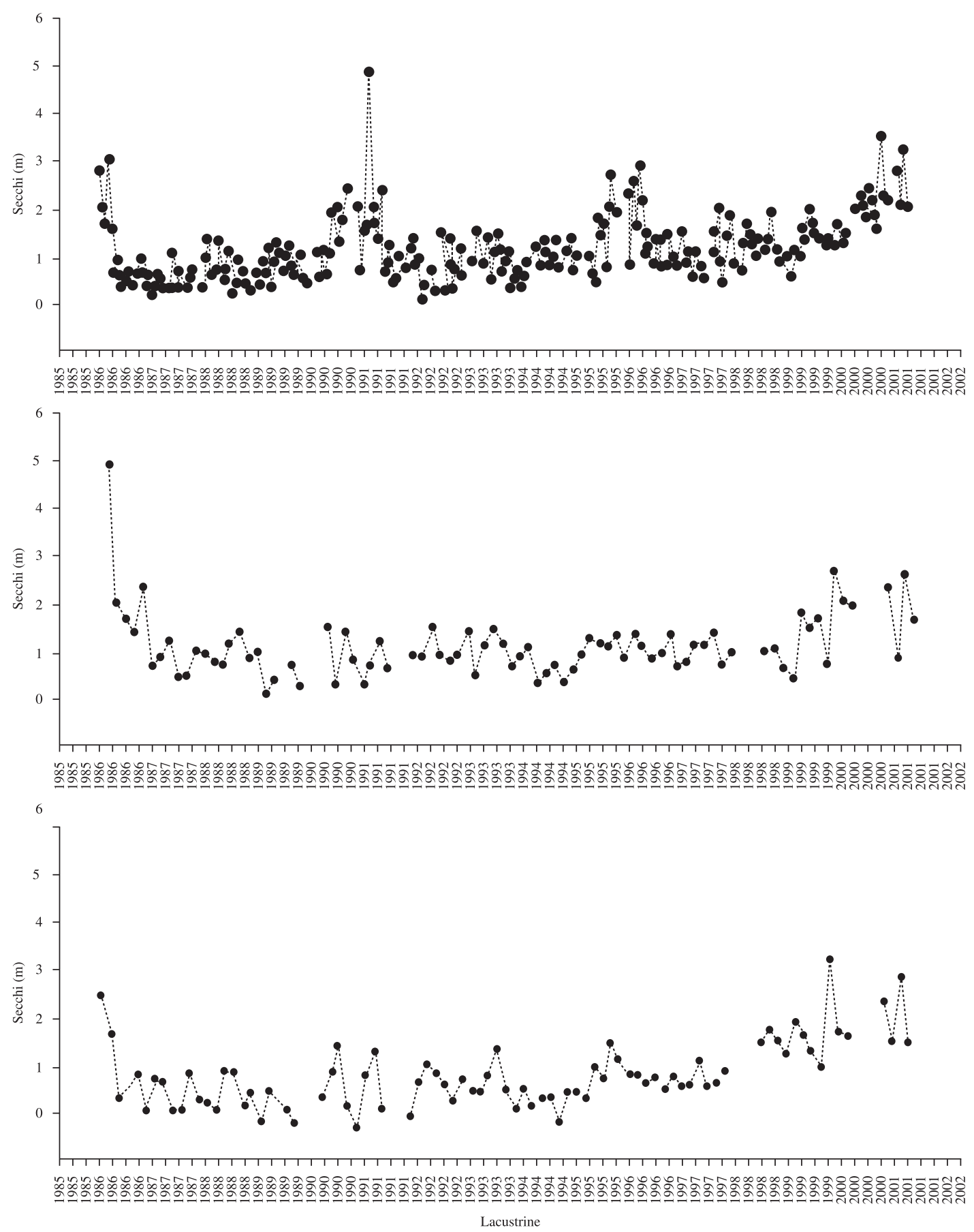

Figure 2. Water transparency and its longitudinal distribution according to the three reservoir zones from 1985 to 2007.

transport and deposition influence the ecological process. In this study, the irregular dynamics of limnological variables may be explained by this process and the by discharges suffered by the Paraná River.

The inspection of the topographical map of Itaipu valley (Stivari et al., 2005), suggests that the topography of the transition zone favours a flow increasing (Tucci, 2002), maximising the contribution of allochthonous material to the reservoir. In the terrestrial area adjacent to the transition zone there are numerous rural properties with rearing pigs and their waste are discarded / washed away without any treatment. Ferrareze et al. (2005) assessed the nutrients transport and material in suspension in different stretches of River Paranapanema (an important left margin tributary of River Paraná) and its tributaries. Their results point 
Table 1. Multiple comparison tests a posteriori between the means of: a) water transparency; b) suspended solids, c) turbidity, d) TKN, e) total phosphorus, f) chlorophyll-a and g) TSI mean by the ANOVAs models in three zones of Itaipu Reservoir, from 1985 to 2008.

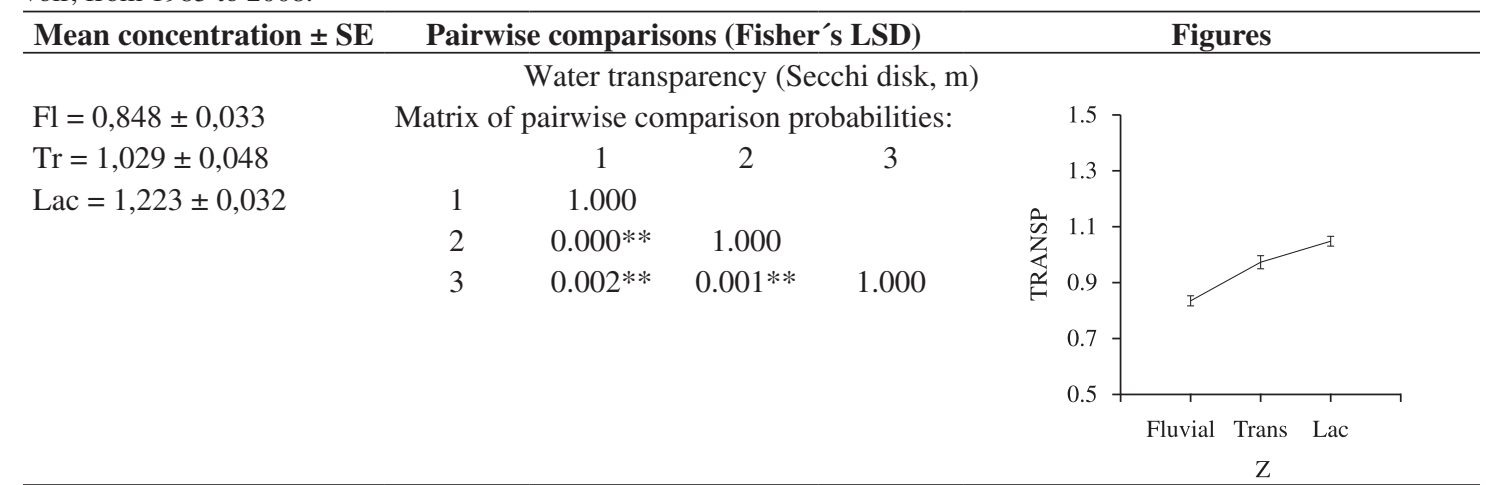

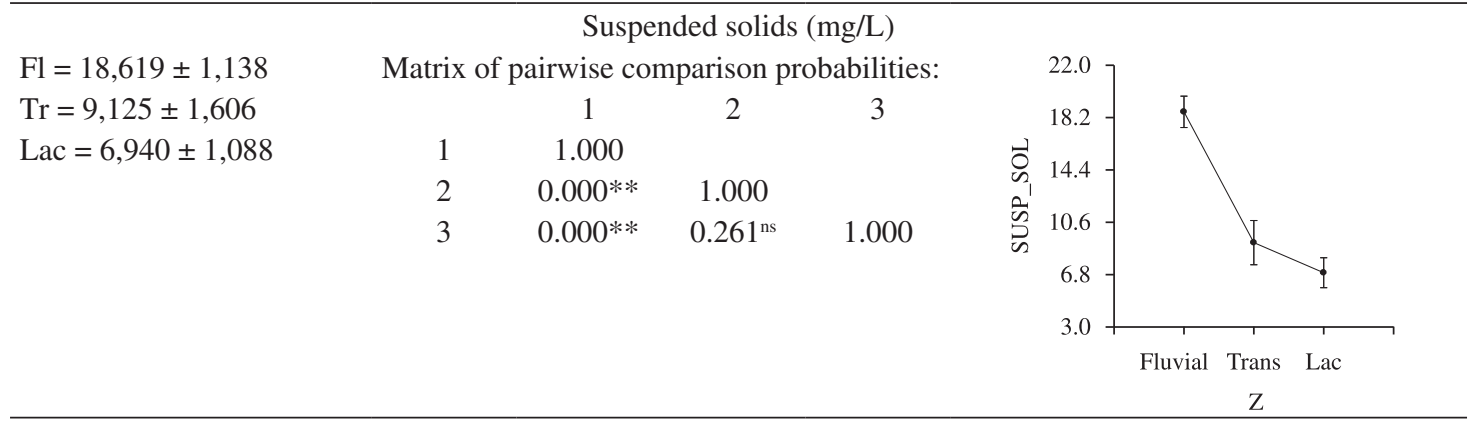

Turbidity (NTU)

\begin{tabular}{lcccc}
$\mathrm{Fl}=22,640 \pm 1,099$ & \multicolumn{5}{c}{ Matrix of pairwise comparison probabilities: } \\
$\mathrm{Tr}=15,943 \pm 1,569$ & 1 & 1 & 2 & 3 \\
$\mathrm{Lac}=10,921 \pm 1,054$ & 2 & $0.000 * *$ & 1.000 & \\
& 3 & $0.000^{* *}$ & $0.008^{* *}$ & 1.000
\end{tabular}

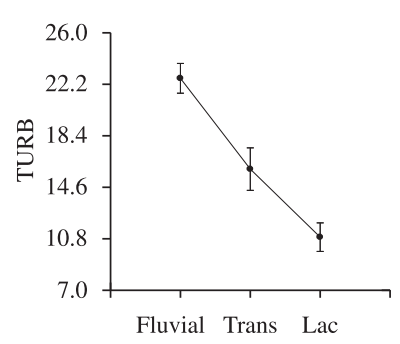

TKN (mg/L)

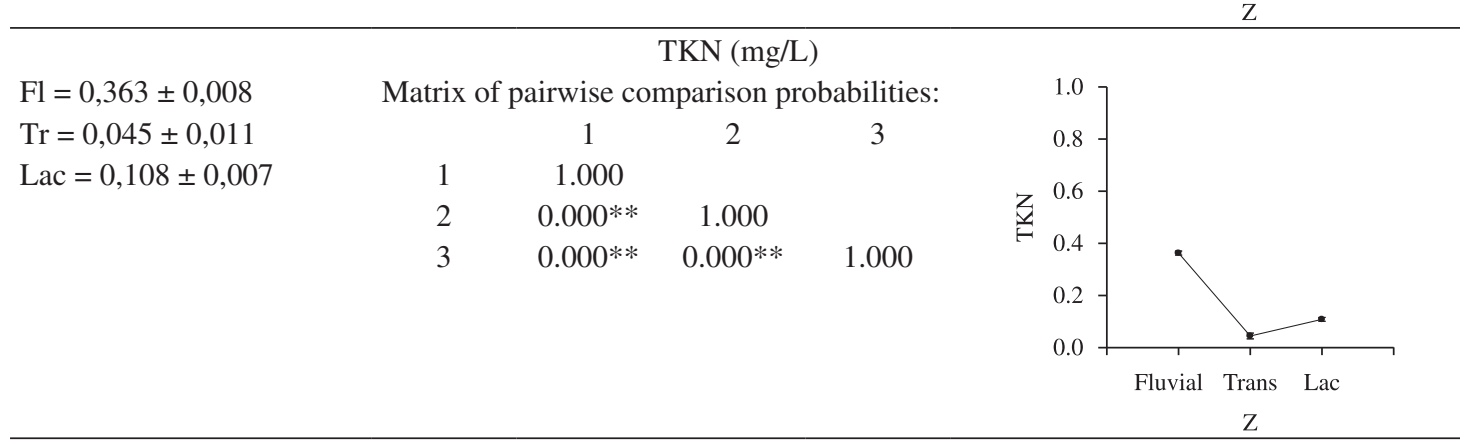

Z

$\mathrm{Fl}=41,818 \pm 1,523$

$\operatorname{Tr}=28,678 \pm 2,175$

$\mathrm{Lac}=21,715 \pm 1,460$
Total phosphorus (mg/L)

Matrix of pairwise comparison probabilities:

$\begin{array}{cccc} & 1 & 2 & 3 \\ 1 & 1.000 & & \\ 2 & 0.000^{* *} & 1.000 & \\ 3 & 0.000^{* *} & 0.008^{* *} & 1.000\end{array}$


Table 1. Continuação...

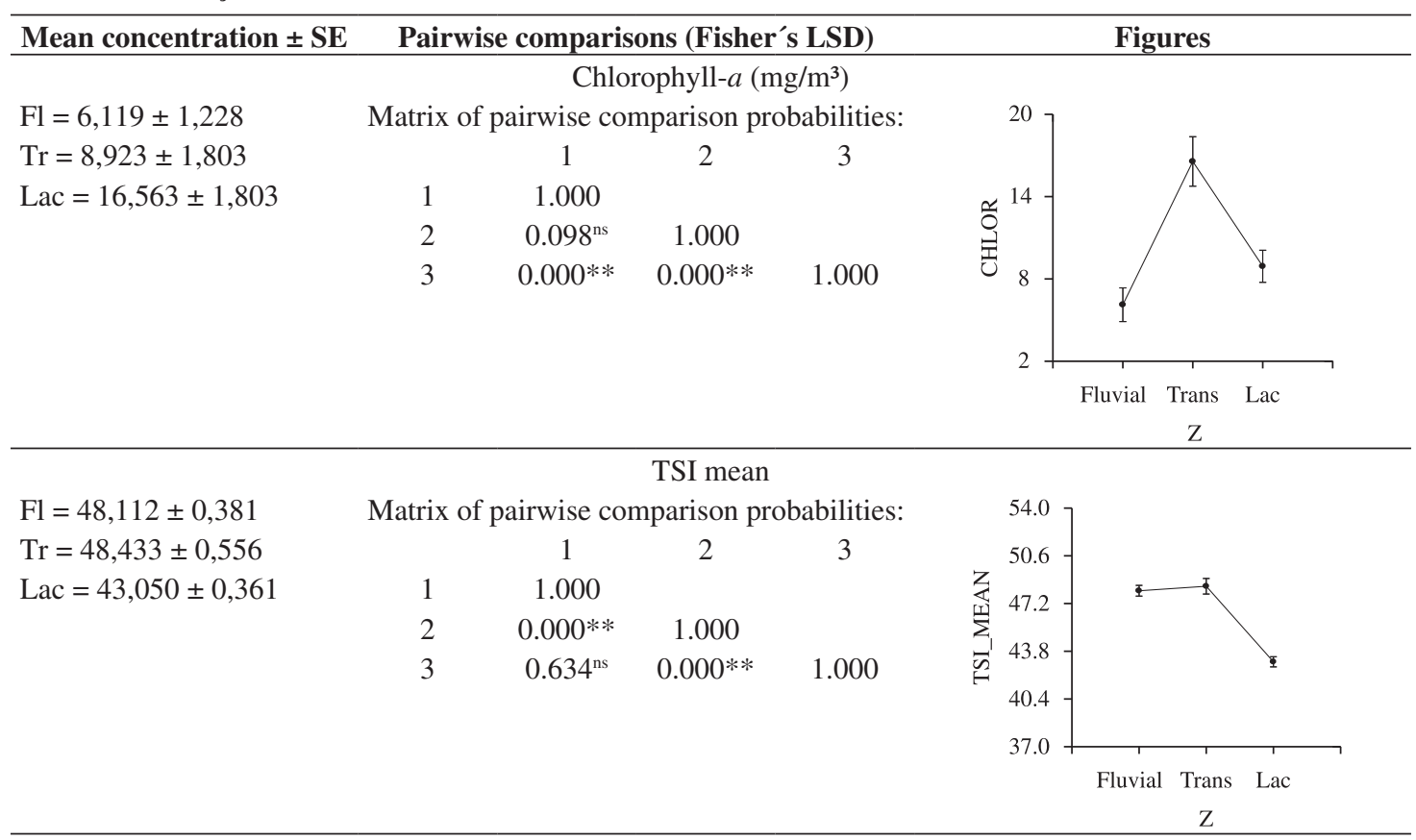

out the hydrological cycle importance, in particular the precipitation, and the lateral and longitudinal dimensions.

Land use and occupation are two factors of extreme importance in reservoir studies. Activities as the monoculture and large pasture areas may increase the nutrient concentration in the aquatic ecosystem. The extensive cultivates areas in Itaipu Brazilian margin contribute to the acceleration of the eutrophication process of the reservoir, while on the Paraguayan side large forested areas still persist. As in other example studies, São Simão Reservoir (MG) showed that the largest nutrient and solids concentrations were detected in those rivers with intense agricultural and cattle activities (Pinto-Coelho et al., 2005) and in the cascade of reservoirs in the Paranapanema River (Nogueira et al., 2005). Roberto et al (2009) observed an increase in transparency of the water downstream from Porto Primavera Dam and the highest values of water transparency observed in recent years in Itaipu Reservoir, in particular in the lacustrine zone $(\mathrm{p}<0.05)$, may be due to the cascading effect caused by the Porto Primavera Dam.

It is well established that water transparency strongly influences the trophic state of aquatic habitats, and light penetration determines the development of phytoplankton and as a consequence, habitat enrichment (Esteves, 1988; Wetzel, 1990; Henry, 1990). The present study showed that the highest concentrations of nutrients were observed in the fluvial zone and the highest concentrations of chlorophyll- $a$ in the transition zone. In contrast, transparency has increased along the longitudinal axis (meaning fluvial zone - lacustrine zone), possibly indicating that these nutrients have been absorbed in the transition zone, where there was an increase in light penetration, increasing the levels of chlorophyll in this area. Finally, watching the lake area, we can infer that nutrients strongly assimilated into the transition zone and the lowest averages in the lacustrine zone, are responsible for the low chlorophyll- $a$ concentrations in this compartment, despite the high penetration of light.

Nitrogen and phosphorous are the main nutrients for the primary producers in aquatic habitats (Esteves, 1988). Ribeiro-Filho (2006) showed that in the Itaipu Reservoir, TKN was the one which presented the best linear and significant relationship with chlorophyll- $a$ concentrations, and a positive and significant relationship with water transparency.

In the Itaipu Reservoir, the smallest water transparencies were registered in the fluvial zone due to the transport of particles and sedimentation. The suspended solids data indicate that as these variables decreases, the water transparency consequently increases, as pointed out by Andrade et al. (1988) and Agostinho et al. (1997). The suspended solids concentration, besides the hydrological cycle and turbidity, is also one of the most important factors that limit the primary production (Calijuri and Tundisi, 1990). Ribeiro-Filho (2006, 2008) pointed to rain as an important factor in relation to water transparency in the Itaipu Reservoir, with a negative correlation between both variables, and noted the importance of measuring these abiotic factors to estimate the productivity of aquatic systems.

In the Itaipu, this variable presented similar values in the three zones, although presenting decreasing mean downriver, in accordance with Ribeiro-Filho (2006) 

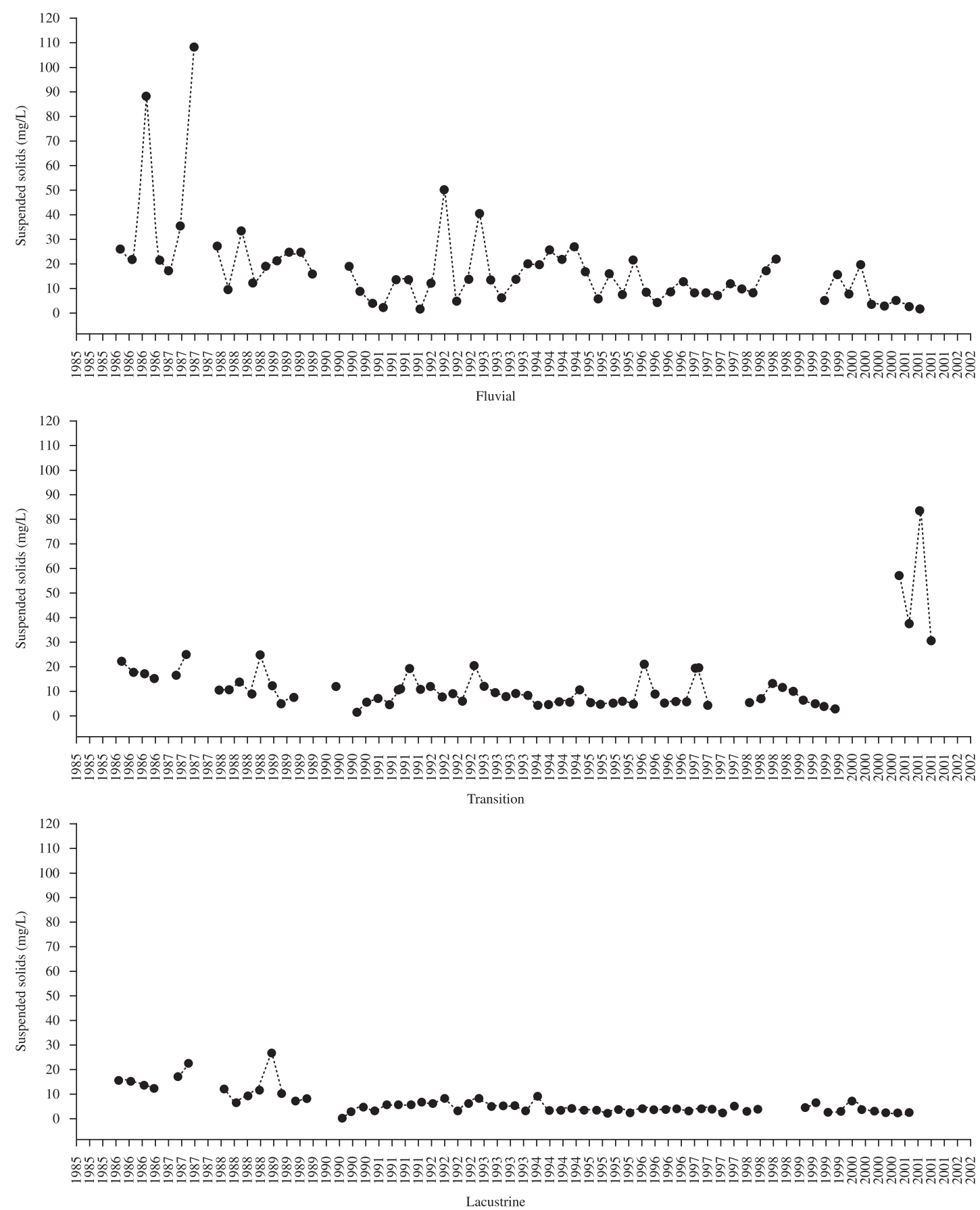

Figure 3. Total suspended solids and longitudinal distribution according to the three reservoir zones from 1985 to 2008.

and Andrade et al. (1988) previous results. The highest turbidity values can be explained by eventual periods of rains in previous periods and during data collection, as observed by Zanata (1999) in Salto Alto Reservoir and Pinto-Coelho et al. (2005) in São Simão reservoir.

The smallest mean concentration of total phosphorus in the lacustrine zone may be explained by the different sedimentation rates along the water course. It is important to point out that in this zone the total phosphorous can more important to limit the primary productivity (clorophill- $a$ ) than the underwater radiation, that increase in direction of the dam (Pagioro and Thomaz, 2002).

The total phosphorus concentrations presented a trend in the distribution and decrease towards the reservoir, as observed by Agostinho et al. (1999) and Andrade et al. (1988). Tundisi et al. (1993) point out that the inhibition of 


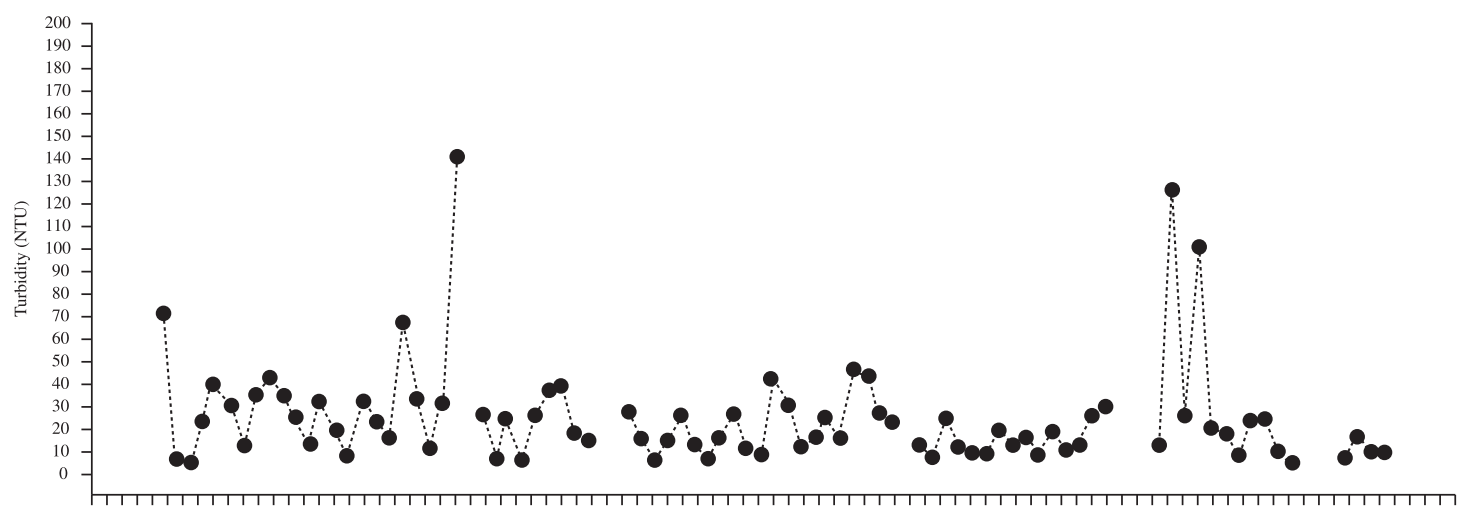

:

Fluvial

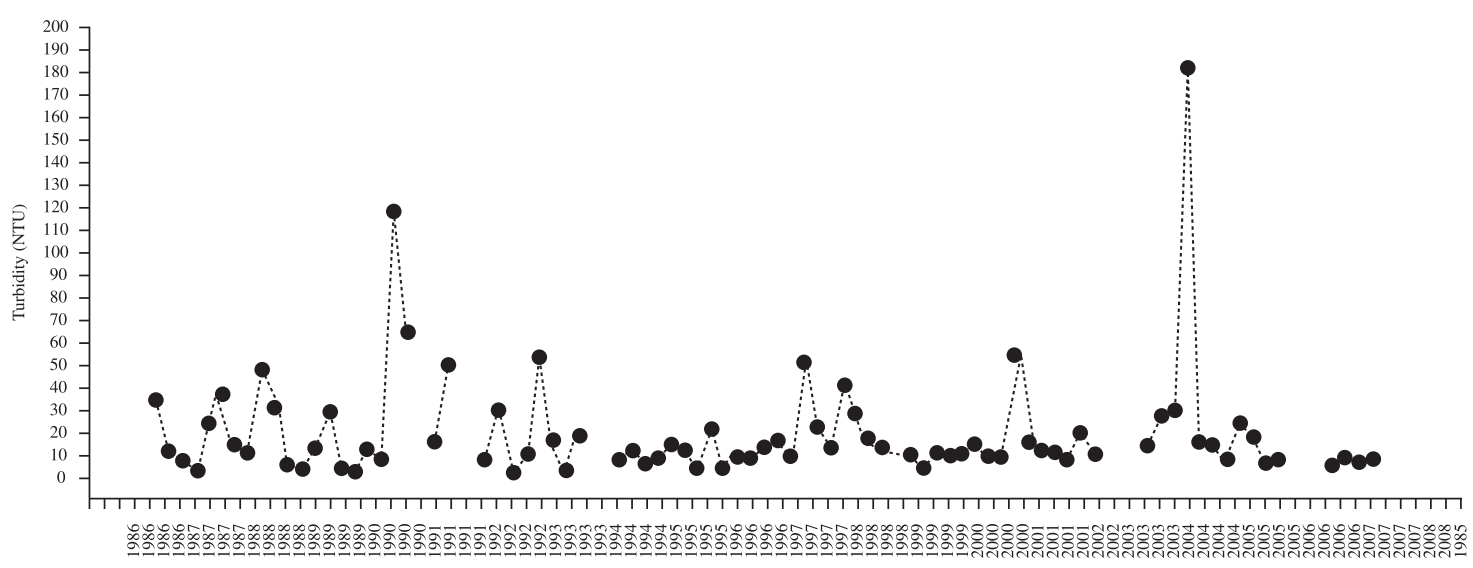

Transition

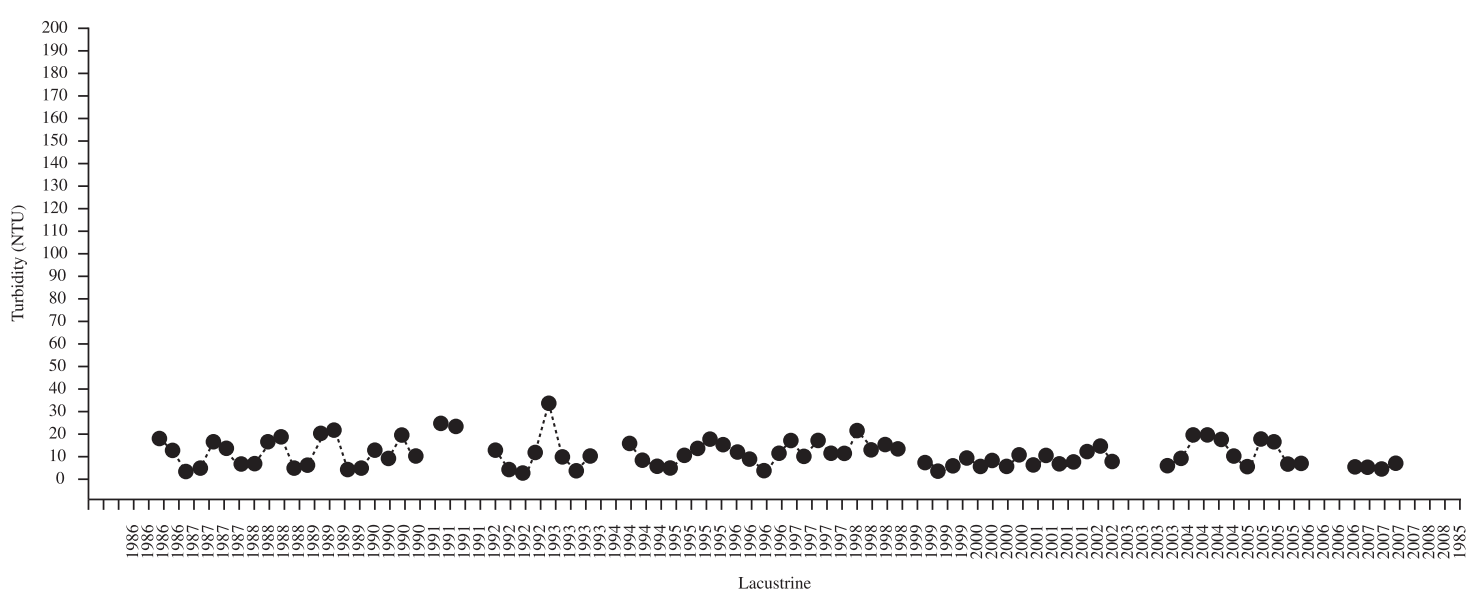

Figure 4. Turbidity and its longitudinal distribution according to the three reservoir zones from 1985 to 2008.

the eutrophication process can be associated to phosphorous retention in the cascade of reservoirs above Itaipu, and studies accomplished by Nogueira et al. (2005) (Paranepanema River) and Roberto et al. (2009) (Paraná River) showed that there is a phosphorous decreasing in cascade reservoirs. In Itaipu Reservoir, the importance of impoundment in Porto Primavera dam could be observed in time scale, because this nutrient had a pronounced decline after 1998 when this reservoir was closed and started to exert major influences on limnological variables downstream.
The primary productivity, which may be expressed indirectly by chlorophyll- $a$ concentration is controlled by the action of factors such as underwater light and nutrients (Henry and Simão, 1990). The phytoplankton community of a reservoir is maintained by the continuous nutrient input (flowing flows) and by the nutrients recycled by zooplankton and fish.

The longitudinal distribution of the chlorophyll- $a$ in the reservoir was constant for the fluvial and lacustrine zones, with statistical equal mean concentrations. The largest 


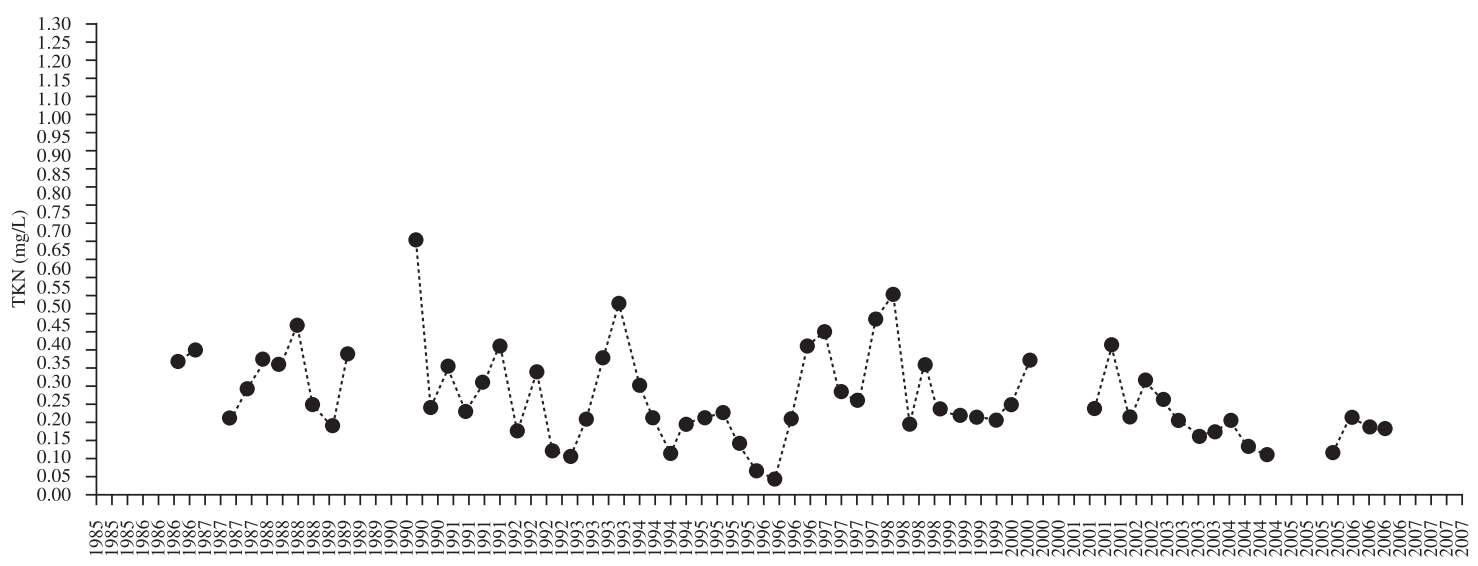

Fluvial

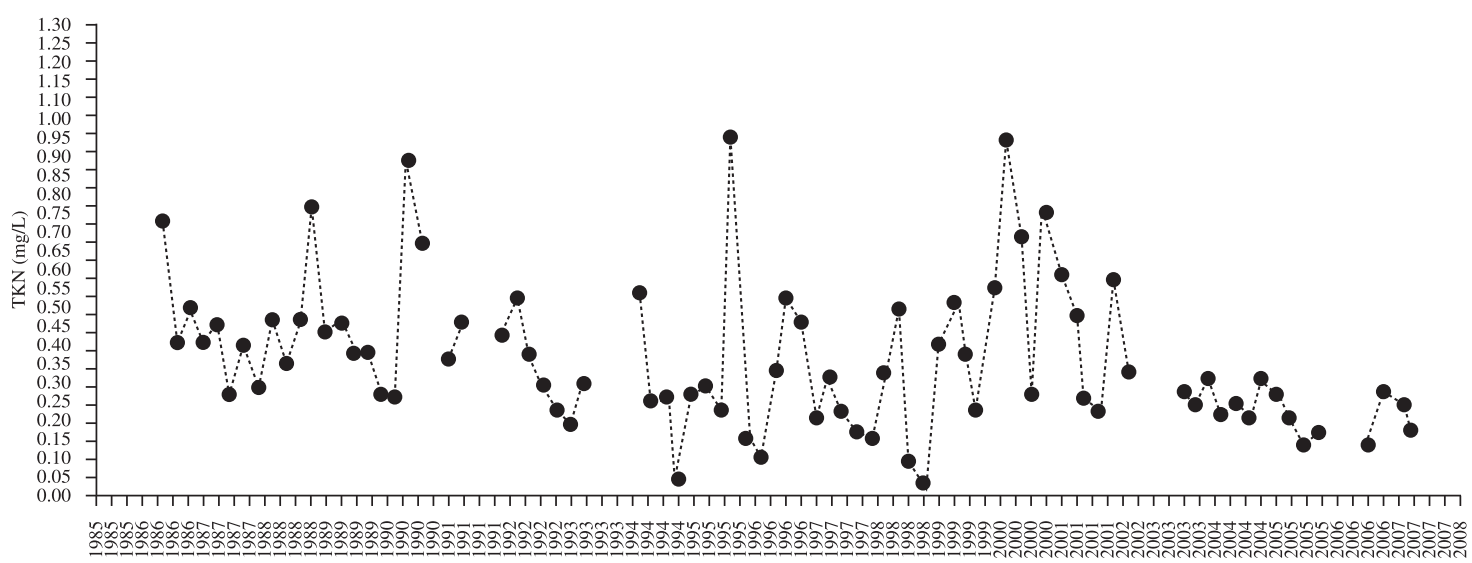

Transition

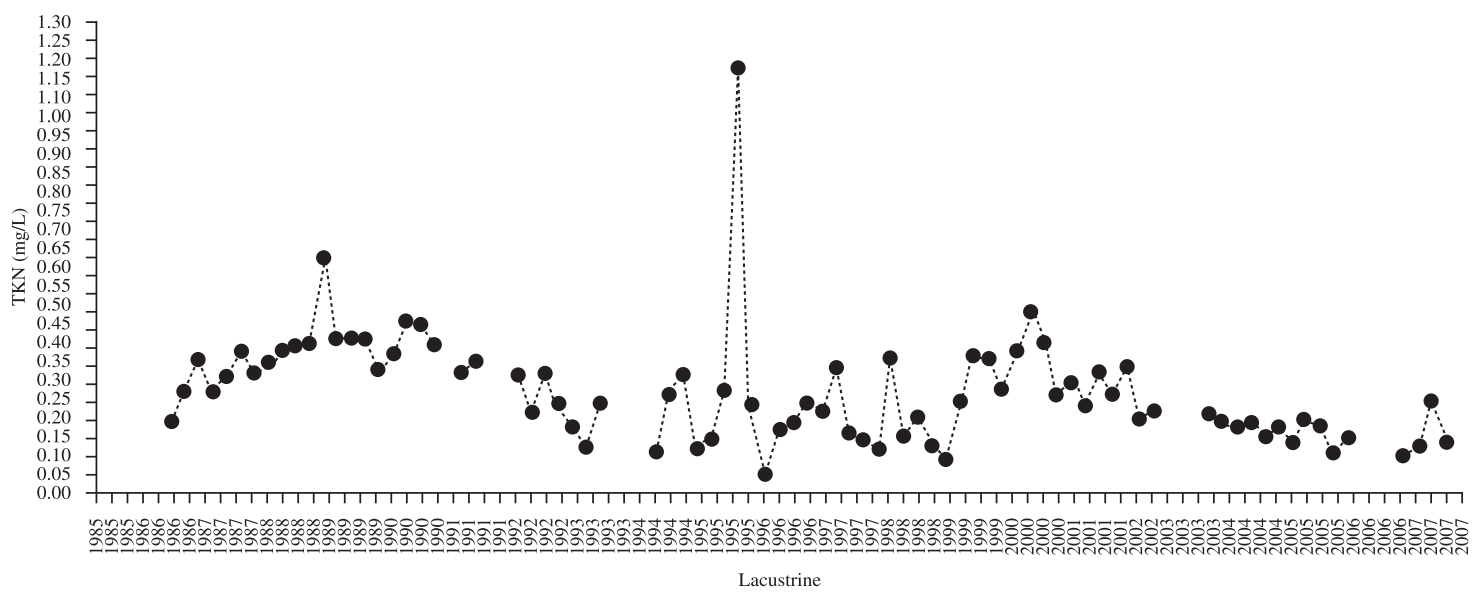

Figure 5. TKN and its longitudinal distribution according to the three reservoir zones from 1985 to 2008.

chlorophyll- $a$ concentrations in the transition zone can be explained by high concentrations of nutrients observed in the fluvial zone and by their possible transport along the longitudinal axis, as discussed earlier and as shown Ribeiro-Filho (2006, 2008). Pagioro et al. (2005) comment that the largest concentrations of chlorophyll- $a$ in the transition zone can be due to the theoretical relationship between light and phosphorous, with a higher concentration in this area, increasing the primary productivity. In this relationship, the possibility of resuspension of forms of phosphorus trapped in the sediment that, associated with light availability, may cause elevated concentrations of chlorophyll- $a$ and phytoplankton (Esteves, 1988).

The Trophic State Index aims to classify aquatic bodies in terms of nutrient enrichment and it is calculated through linear regression models (Toledo Junior et al., 1983). The results showed that the fluvial and the transition zones present a higher trophic degree, which can be related to 

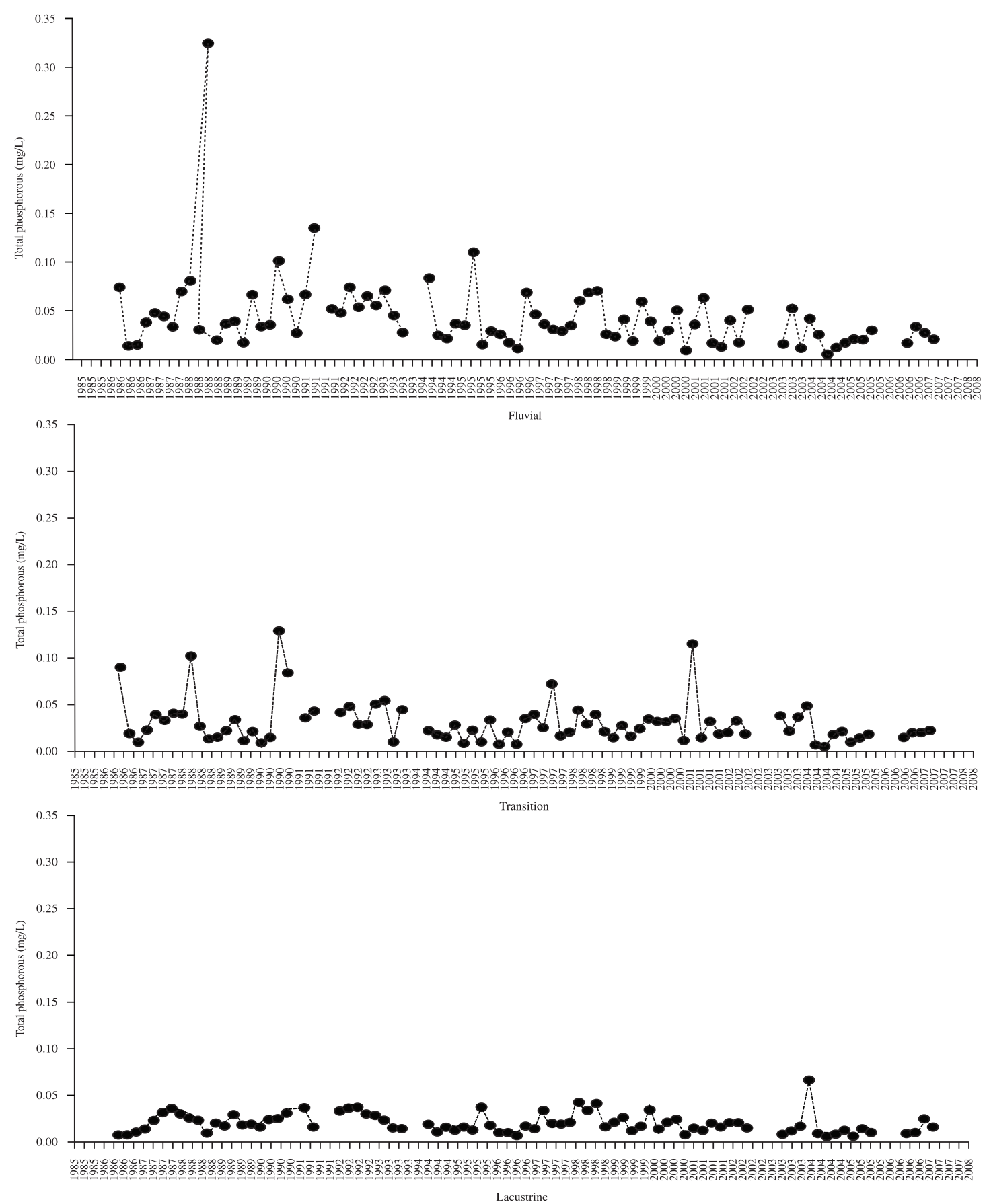

Figure 6. Total phosphorous and its longitudinal distribution according to the three reservoir zones from 1985 to 2008.

the largest contribution of nutrients (diffuse pollution). For this reason, we used the weighted mean of the calculated indices, being attributed a smaller weight to the water transparency index (readings of Secchi disk), without removing it from the mean TSI. The results obtained show that the fluvial and the transition zones present higher trophic degree, which can be related to the largest contribution of nutrients (diffuse pollution) or, mathematically, the effect of higher concentrations of nutrients and chlorophyll- $a$ and the lowest values of transparency found in these regions.

The mean TSI values indicate a small improvement of water trophic state, following a spatial/temporal pattern. The calculated values in the lacustrine zone indicate that this area is oligotrophic, according to Toledo Junior et al. (1983). The fluvial and the transition zones presented higher values, reaching concentrations indicating a mesotrophic 

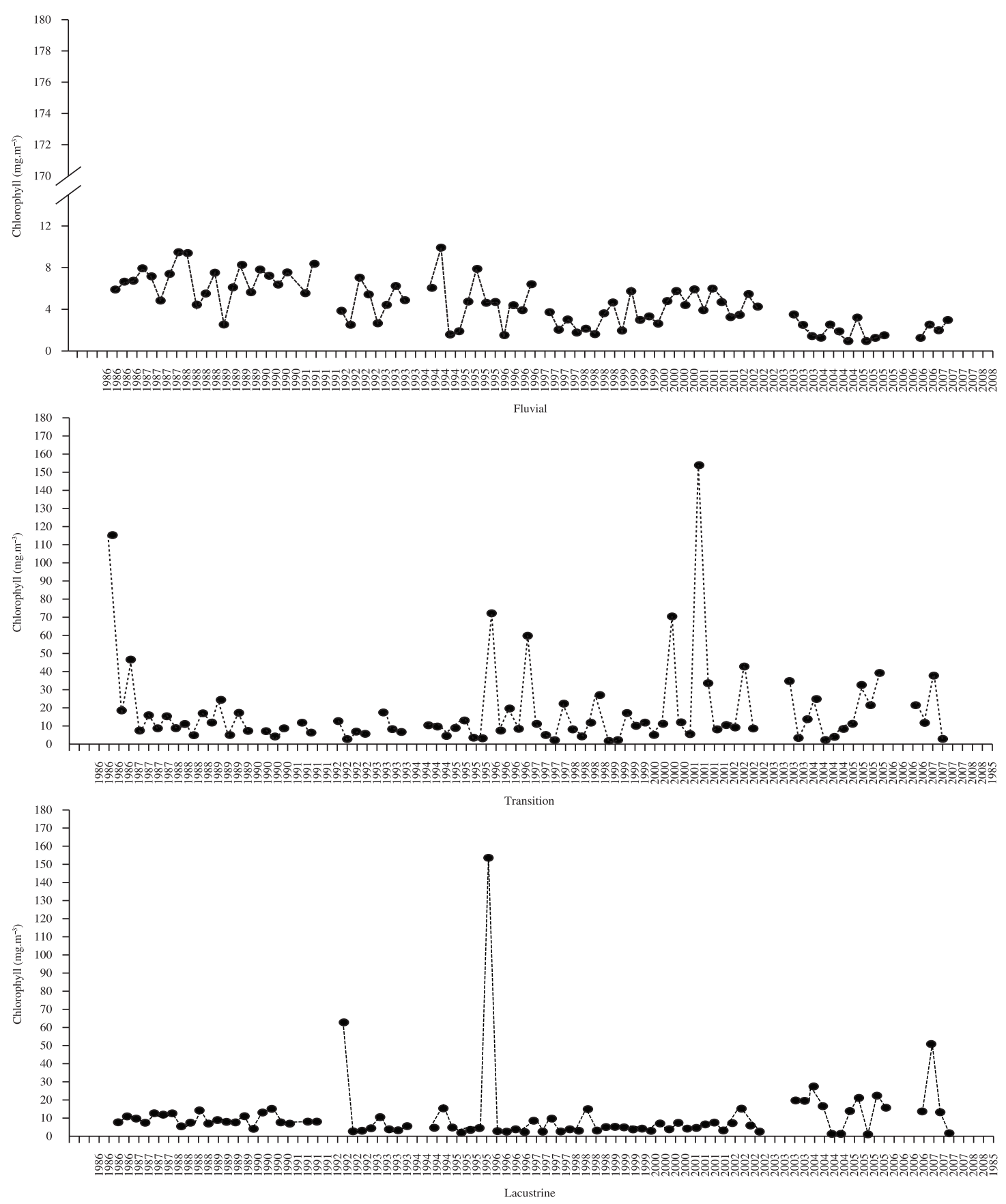

Figure 7. Chlorophyll- $a$ concentration and its longitudinal distribution according to the three reservoir zones from 1985 to 2007.

state. In spite of that, the mean value calculated for the whole reservoir, indicated that it may be classifized as mesotrophic, corroborating Ribeiro-Filho (2006) and Andrade et al. (1988). This change in the trophic state among the three different zones was also verified by Zanata (1999) and Minillo (2005) and these authors pointed out the precipitation and the diffuse pollution as factors that better explain the changes in the trophic state. Another important factor to be considered is the cascade system above Itaipu, also present in its main tributaries such as the Rivers Tietê, Grande and Paranapanema, which supply the River Paraná. This factor might have great influence, as the nutrient concentrations and particulate material are deposited and reduced along the reservoirs cascade (Nogueira et al., 2005; Andrade et al., 1988).

Based on this study, we recommend a review of monitoring points in order to enable a wider coverage of areas of the reservoir, particularly in relation to the 


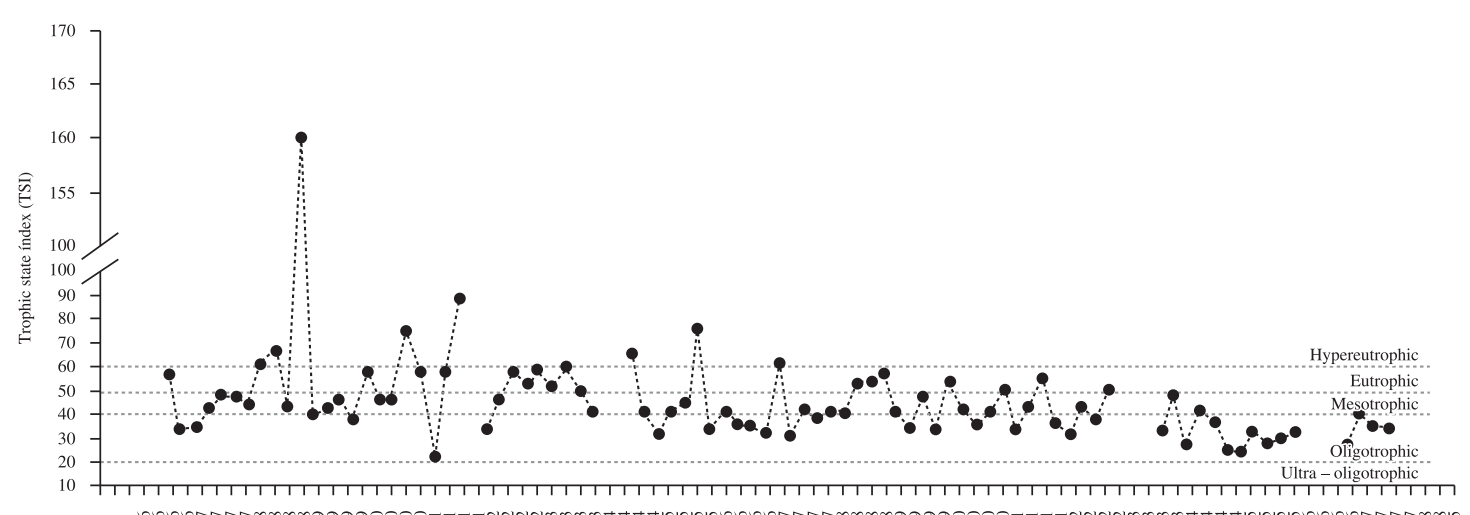

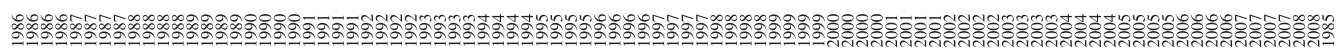

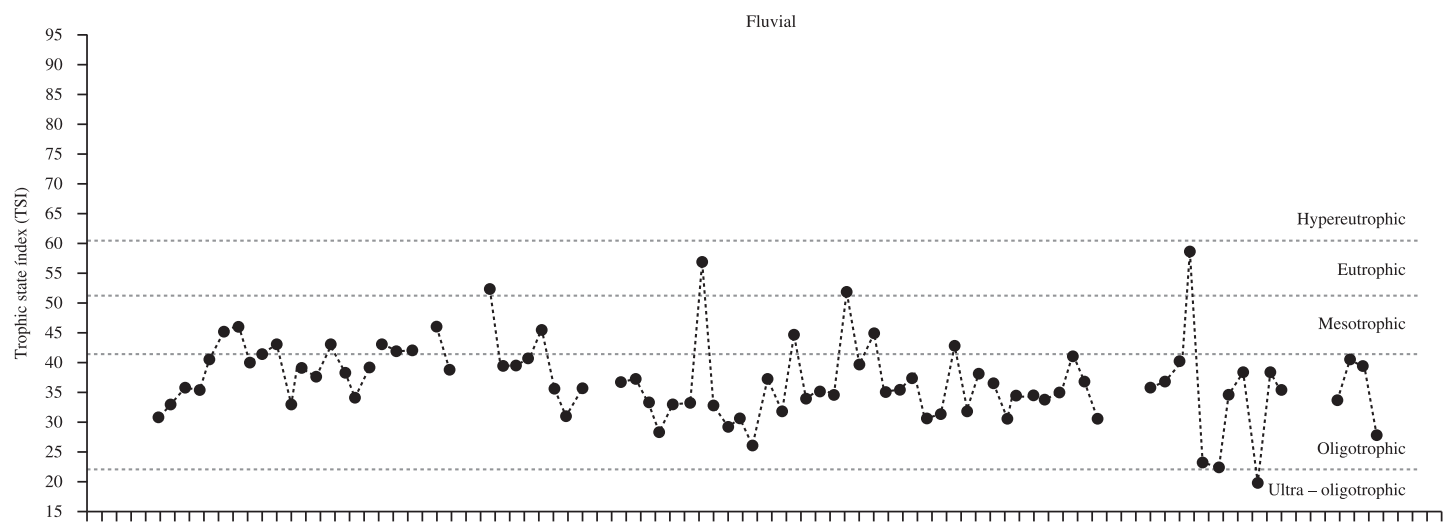

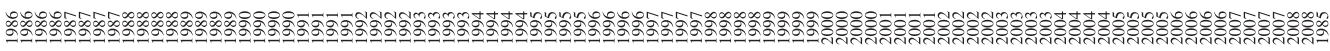

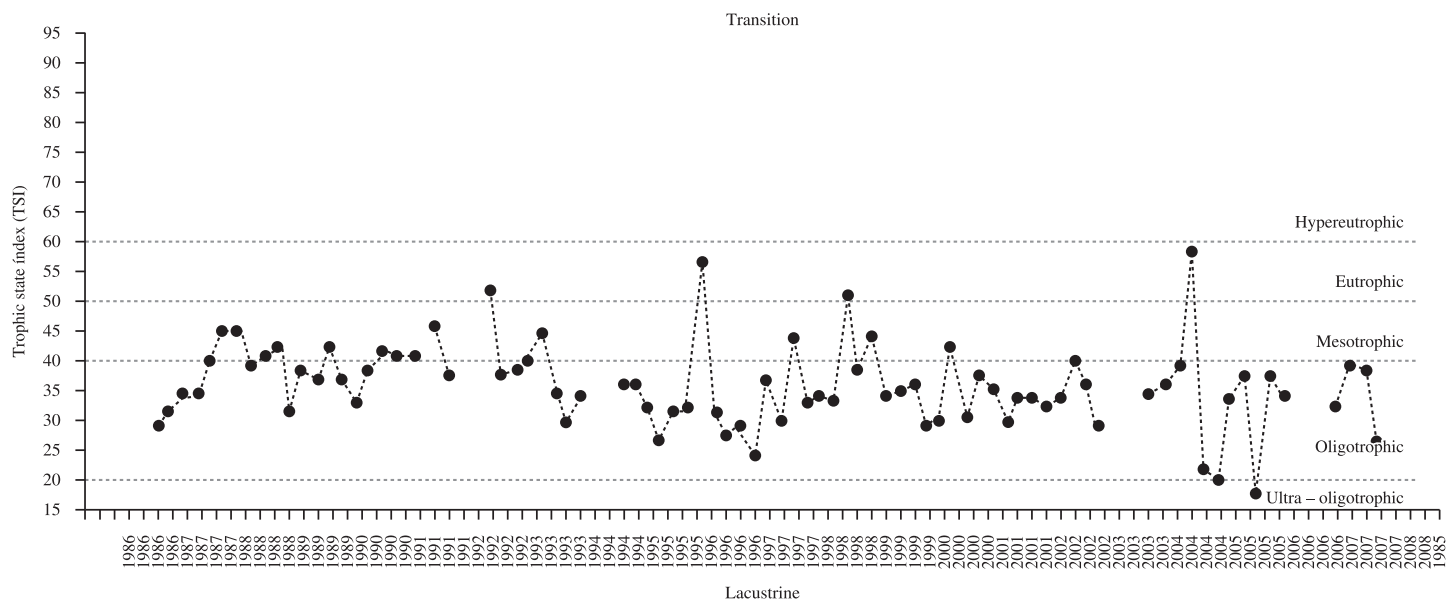

Figure 8. Trophic state index (TSI) and its longitudinal distribution according to the three reservoir zones from 1985 to 2008

shortcomings of the transition and the lacustrine zones (central regions of these zones), whose points are close to regions of the tributaries, river characteristics and may confer the monitored variables.

Acknowledgements - This paper is part of a Final Pos-doc Report by the Senior author supervised by MPJr. We thank FAPESP (Processo $n^{\circ}$. 07/50986-9) and CNPq for the financial support and UNESP for the facilities. We thank Itaipu Binational by the availability of data leading to this work.

\section{References}

AGOSTINHO, AA., FERREIRA, VS., JÚLIO JUNIOR, HF., MINTE-VERA, CV., OLIVEIRA, EF., OKADA, EK., PAGIORO, TA., ROBERTO, MC., SUZUKI, HI., THOMAZ, SM. and ABUJANRA, F., 1997. Variações espaço-temporais na ictiofauna e suas relações com as condições limnológicas no reservatório de Itaipu. Relatório Anual. Maringá. 330 p.

AGOSTINHO, AA., MARQUES, EE., AGOSTINHO, CS., ALMEIDA, DA., OLIVEIRA, RJ. and DE MELO, RB., 2007. 
Fish ladder of Lajeado Dam: migrations on one-way routes?. Neotropical Ichthyology, vol. 5, n. 2, p. 121-130.

AGOSTINHO, AA., OKADA, EK., GOMES, LC., AMBRÓSIO, AM. and SUZUKI, HI., 2005. Reservatório de Itaipu: estatística de rendimento pesqueiro. Relatório de pesquisa.

AGOSTINHO, AA., OKADA, EK. and GREGORIS, J., 1999. A pesca no Reservatório de Itaipu: Aspectos sócio-econômicos e impactos do represamento In HENRY R. (Ed.). Ecologia de reservatórios: estrutura, função e aspectos sociais. FUNDIBIO/ FAPSP. 800 p.

American Public Health Association - APHA, 1985. Standard Methods for the Examination of Water and Wastewater. 16nd ed. Washington: APHA. $1134 \mathrm{p}$.

ANDRADE, LF., BRUNKOW, RF., XAVIER, CF. and DOMINGUES, LL., 1988. Fitoplâncton e características físicoquímicas do reservatório de Itaipu. In TUNDISI, JG. (Ed.). Limnologia e Manejo de Represas. Série: Monografias em Limnologia, vol. 1 (tomo 1).

CALIJURI, MC. and TUNDISI, JG., 1990. Limnologia Comparada das Represas do Lobo (Broa) e Barra Bonita - Estado de São Paulo: Mecanismos de Funcionamento e Bases para o Gerenciamento. Revista Brasileira de Biologia = Brazilian Journal of Biology, vol. 50, no. 4, p. 893-913.

CARLSON, RE., 1977. A trophic state index for lakes. Limnology \& Oceanography, vol. 22, p. 361-80.

DRENNER, RW., SMITH, JD. and THRELKELD, ST., 1996. Lake trophic state and the limnological effects of omnivorus fish. Hydrobiologia, vol. 319, p. 213-223.

ESTEVES, FA., 1988. Fundamentos de limnologia. Rio de Janeiro: Editora Interciência, FINEP. 575 p.

FERRAREZE, MFF., NOGUEIRA, MG. and VIANNA, NC., 2005. Transporte de nutrientes e sedimentos no rio Paranapanema (SP/ PR) e seus principais tributários nas estações seca e chuvosa. In NOGUEIRA, MG., HENRY, R. and JORCIN, A. (Eds.) Ecologia de Reservatórios. São Carlos: Ed. Rima. 459 p.

HANSON, JM. and LEGGET, WC., 1982. Empirical prediction of fish biomass and weight. Canadian Journal of Fisheries and Aquatic Sciences, vol. 39, p. 257-263.

HENRY, R., 1990. Amônia ou fosfato como agente estimulador do crescimento do fitoplâncton na represa de Jurumurim (Rio Paranapanema, SP)? Revista Brasileira de Biologia = Brazilian Journal of Biology, vol. 50, no. 4, p. 883-892.

HENRY, R. and SIMÃO, AC. 1990. Aspectos sazonais da liberação potencial por N, P e Fe no fitoplâncton na represa de Barra Bonita (Rio Tietê, SP). Revista Brasileira de Biologia $=$ Brazilian Journal of Biology, vol. 48, no. 1, p. 1-14.

Instituto de Análises do Paraná - IAP, 2003. Relatório anual. Curitiba: Contrato Itaipu Binacional, Instituto Ambiental do Paraná. 107 p. Estudos Limnológicos do Reservatório de Itaipu.

KIMMEL, BL., LIND, OT. and PAULSON, LJ., 1990. Reservoir primary production. In THORTON, KW., KIMMEL, BL. and PAYNE, FE. (Eds.). Reservoir Limnology: ecological perspectives. New York: John Wiley \& Sons. p. 133-194.

MARFALEF, MW., 1975. Tipology of reservoir. Verhandlungen des Internationalen Verein Limnologie, vol. 19, p. 1841-1848.

McQUEEN, JD., 1990. Manipulating lake community structure: where do we go from here? Freshwater Biology, vol. 23, p. 613-620.
-, 1998. Freshwater food web biomanipulation: A powerful tool for water quality improvement, but maintenance is required. Lakes \& Reservoirs: Research and Management, vol. 3, p. 83-94.

MINILLO, A. 2005. Análise da distribuição, densidade e toxicidade de florações de cianobactérias e suas toxinas nos reservatórios do Médio e Baixo rio Tietê (SP) e relação com as características limnológicas do sistema. São Carlos: Universidade de São Paulo. 394 p. Tese de Doutorado em Engenharia Ambiental.

NOGUEIRA, MG., JORCIN, A., VIANNA, NC. and DE BRITTO, YCT., 2005. Reservatório em Cascata e os efeitos na limnologia e Organização das Comunidades Bióticas (Fitoplâncton, Zooplâncton e Zoobentos) - Um Estudo de Caso no Rio Paranapanema (SP/ PR). In NOGUEIRA, MG., HENRY, R. and JORCIN, A. (Eds.). Ecologia de Reservatórios. São Carlos: Ed. Rima. 459 p.

PAGIORO, TA. and THOMAZ, SM., 2002. Longitudinal patterns of sedimentation in a deep monomitc subtropical reservoir Itaipu (Brazil- Paraguay). Archiv für Hydrobiologie, vol. 154, no. 3, p. $515-528$.

PAGIORO, TA., THOMAZ, SM. and ROBERTO, MC., 2005. Caracterização Limnológica Abiótica dos Reservatórios. In RODRIGUES, L., THOMAZ, SM., AGOSTINHO, AA. and GOMES, LC. (Eds.). Biocenose em Reservatórios: Padrões espaciais e temporais. São Carlos: Rima Editora.

PEDRO, F., 1995. Alimentação e Comportamento Predatório do tucunaré Cichla ocellaris, Bloch \& Schneider, 1801 (Osteichihyes: Cichlidae). João Pessoa: Universidade Federal da Paraíba. 132 p. Dissertação de Mestrado em Engenharia Ambiental.

PERSSON, L., ANDERSSON, G., HAMIRIN, SF. and JOHANSSON, L., 1988. Predator regulation and primary production along the productive gradient of temperate lake ecosystems. In CARPRNTER, SR. (Ed.). Complex Interactions in Lake Communities. New York: Springer-Verlag. p. 53-59.

PINTO-COELHO, RM., AZEVEDO, LMA., RIZZI, PEV., BEZERRA-NETO, JF. and ROLLA, ME., 2005. Origens e Efeitos do Aporte Externo de Nutrientes em um Resevatório tropical de Grande Porte: Reservatório de São Simão (MG/GO). In NOGUEIRA, MG., HENRY, R. and JORCIN, A. (Eds.). Ecologia de Reservatórios. São Carlos: Ed. Rima. 459 p.

QUIROS, R., 1990. Predictors of relative fish biomass in lakes and reservoirs of Argentina. Canadian Journal of Fisheries and Aquatic Sciences, vol. 47, p. 928-939.

RIBEIRO-FILHO, RA., 1999. Caracterização de dietas alimentares de peixes predadores em açudes de Pernambuco e no Lago Paranoá (Brasília - DF). Recife: Universidade Federal Rural de Pernambuco. 52 p. Monografia de Graduação em Engenharia de Pesca.

-, 2006. Relações tróficas e limnológicas no reservatório de Itaipu: uma análise do impacto da biomassa pesqueira nas comunidades planctônicas. São Carlos: Universidade de São Paulo. 139 p. Tese de Doutorado em Ciências da Engenharia Ambiental.

-, 2008. Evolução histórica das Relações Tróficas e limnológicas no Reservatório de Itaipu: Efeitos Top-down e Bottom-up na produção Pesqueira. Rio Claro: Universidade Estadual de São Paulo. 102 p. Relatório final.

ROBERTO, MC., SANTANA, NF., and THOMAZ, SM. 2009. Limnology in the Upper Paraná River floodplain. Brazilian Journal of Biology, vol. 69, Suppl. 2, p. 717-725.

SHAPIRO, J., LAMARRA, V. and LYNCH, M., 1975. Biomanipulation, an ecosystem approach to lake restoration. In 
BREZONIK, P. and FOX, L. (Eds.). Proceedings of a Symposium on Water Quality Management through Biological Control. Gainesville: University Florida Press. p. 85-96.

SONDERGAARD, M., JEPPESEN, E. and, BERG, S., 1997. Pike (Esox lucius) stocking as a biomanipulation tool 2. Effects on lower trophyc levels in lake Lyng. Denmark. Hydrobiologia, vol. 342-343, p. 319-325.

SOUZA FILHO, EE. Evaluation of the Upper Paraná River discharge controlled by reservoirs. Brazilian Journal of Biology, vol. 69, Suppl. 2, p. 707-716.

SOUZA FILHO, EE. and STEVAUX, JC., 1997. Geologia e geomorfologia do complexo do rio Baía, Curutuba, Ivinheima. In VAZZOLER, AEAM., AGOSTINHO, AA. and HAHN, NS. (Eds.). A Planíciede Inundação do Alto Rio Paraná: aspectos físicos, biológicos e socioeconômicos. Maringá: EDUEM. p. 179-208.

STARLING, FLM., 1998. Development of biomanipulation strategies for the remediation of eutrophication problem in a urban reservoir- Lago Paranoá. Escócia: University of Stirling. 159 p. PhD Thesis.

STIVARI, SS., OLIVEIRA, AP. and SOARES, J., 2005. On the climate impact of the local circulation in the Itaipu Lake Area. Climatic Change, vol. 72, p. 103-121

STRAŠKRABA, M. and TUNDISI, JG., 2000. Diretrizes para $o$ Gerenciamento de Lagos. São Carlos: Instituto Internacional de Ecologia. 258 p.

THORNTON, KW., 1990. Perspectives on reservoir limnology. In THORTON, KW., KIMMEL, BL. and PAYNE, FE. (Eds.). Reservoir Limnology: ecological perspectives. New York: A Wiley-Interscience. p. 1-13
TOLEDO JUNIOR, AP., TALARTICO, M., CHINEZ, SJ. and AGUDO, EG., 1983. A aplicação de modelos simplificados para a avaliação do processo de eutrofização em lagos e reservatórios tropicais. In Anais do 12nd Congresso Brasileiro de Engenharia Sanitária e Ambiental, 1983. Camburiú. p. 34

TUCCI, CEM., 2002. Escoamento superficial. In TUCCI, CEM. (Ed.). Hidrologia: Ciência e Aplicação. 3nd ed. Porto Alegre: Editora da UFRGS.

TUNDISI, JG., 1990. Distribuição Espacial, Sequiência Temporal e Ciclo Sazonal do Fitoplâncton em Represas: Fatores Limitantes e Controladores. Revista Brasileira de Biologia = Brazilian Journal of Biology, vol. 50, no. 4, p. 937-955.

TUNDISI, JG., MATSUMURA-TUNDISI, T. and CALIJURI, MC., 1993. Limnology and management of Reservoirs in Brazil. In STRAŠKRABA, M., TUNDISI, JG. and DUNCAN, A. (Eds.). Comparative reservoir limnology and water quality management. Dordrecht: Kluwer Academic.

WETZEL, RG., 1990. Reservoir ecosystems: conclusions and speculations. In THORNTON, KW., KIMMEL, BL.and PAYNE, FE. (Eds.). Reservoir Limnology: ecological perspectives. New York: A Wiley-Interscience. p. 227-238.

-, 2001. Limnology: Lakes and river ecosystems. San Diego: Academic press.

ZANATA, LH., 1999. Heterogeneidade ambiental no reservatório de Salto Grande (Americana-SP) com ênfase na distribuição das populações de Cladocera. São Carlos: Universidade de São Paulo. 218p. Dissertação Mestrado. 